\title{
ORIGINAL ARTICLE \\ Bat activity in the interior of Arabuko-Sokoke Forest and adjacent farmlands in Kenya
}

\author{
Simon Musila ${ }^{1, *}$, Robert Syingi ${ }^{1,}{ }^{*}$, Nathan Gichuki ${ }^{2}$, Ivan Castro-Arellano ${ }^{3}$
}

\begin{abstract}
${ }^{1}$ Mammalogy Section, Zoology Department-National Museums of Kenya, Nairobi, Kenya.

${ }^{2}$ School of Biological Sciences, University of Nairobi, ChiromoNairobi, Kenya.

${ }^{3}$ Department of Biology, Texas State University-San Marcos, 601 University Drive, San Marcos, TX-USA.

*Corresponding author e-mails: surnbirds@gmail.com robertsyingi@gmail.com
\end{abstract}

DOI: https://doi.org/10.14709/ BarbJ.11.1.2018.05

Keywords: acoustic sampling, passes, insectivorous bats, mistnets, agricultural lands

received: March, 08th 2018 accepted: July, 21st 2018

\begin{abstract}
Although the coastal forests in Kenya are highly threatened by human activities, limited bat research has been undertaken in them or the human-modified habitats around them. We investigated insectivorous bat activity in Arabuko-Sokoke Forest (ASF) and adjacent farmlands, in order to understand how each habitat was used by bats. Bat activity was sampled with Pettersson D240X ultrasound detectors at 69 stations in different vegetation types in ASF (Cynometra forest, Brachystegia woodland and mixed forest) and farmlands (mango, coconut and mixed plots). The detector was always tuned to $33 \mathrm{kHz}$, and bat passes were counted along 10-minute $400 \mathrm{~m}$ transects at the start of each sampling hour in each station. In each activity survey station, insectivorous bats were also captured in mist-nets in order to determine which of the detector targeted bats could be captured. A total of 14,727 bat passes were counted in both habitats, which included 10,552 in the farmlands and 4,175 in ASF. The largest numbers of insectivorous bats were captured in farmlands. The mean number of bat passes per night in farmlands $(152.9 \pm 13.2)$ was significantly higher than in ASF $(60.5 \pm 4.6)(d f=68, \mathrm{t}=-8.671, \mathrm{P}<0.05, \mathrm{~N}=69)$. There was no significant difference in the sampled medians of bat passes in the three main vegetation types both in the interior of the forest and in farmlands. Bat activity was highest during the rainy season. Bat activity in both habitats peaked at $1900 \mathrm{hr}$ (i.e. just after sunset), sharply declined to the lowest level at midnight, and then maintained a gradual increase from two to five in the morning. Although the farmlands in the study area had completely lost the indigenous vegetation found in ASF, some bat species, probably those more adapted to humanized environments, were found to use these habitats for foraging. This emphasizes the need for more bat research in humanmodified ecosystems in Africa in order to understand these patterns and establish proper conservation guidelines.
\end{abstract}

\section{INTRODUCTION}

Although deforestation is one of the biggest threats to global biodiversity (Brooks et al. 2002, Gaston et al. 2003), it will continue in the future together with massive expansion of human-modified ecosystems and will consequently cause extinctions of many tropical forest species (Bradshaw et al. 2009). About $40 \%$ of the earth terrestrial ecosystem is covered by agricultural areas (FAOSTAT 2011). Agricultural areas support much of the world's biodiversity (Dixon 2012, Tilman 1999, Foley et al. 2005, Tscharntke et al. 2005) and have been the focus of many studies in recent years (Wickramasinghe et al. 2003, Johnson et al. 2008, Miller et al. 2009). The order Chiroptera is one of the most diverse and second largest groups of mammals (Kunz \& Pierson 1994) and provides important ecosystems services including pollination (Kelm et al. 2008), seed dispersal (Medellin \& Goana 1999) and control of agricultural insect pests (Boyles et al. 2011). Bats are highly mobile species (McCracken et al. 2012), and capable of exploring large areas during foraging in a single night (Treitler et al. 2016). However, the massive expansion of agricultural ecosystems and deforestation will eventually threaten the survival of forest bat assemblages (Jones et al. 2009, Kunz et al. 2011, Williams-Guillén et al. 2016). Agricultural intensification affects bats survival due to the extensive vegetation cover clearance, chemical pests control and the application of fertilizers to maximize crop production (Williams-Guillén et al. 2016). Because human population is on the increase worldwide, the pressure to open more areas for agricultural production and augment food productivity per ha will also increase, and consequently will result in the loss of more foraging and roosting habitats for many bat species. Most natural areas globally exist as 'islands' in the midst of human-modified habitats. Thus, understanding bat species found in these remaining natural areas with agro-ecosystems around them, as well as how both habitats are used by bats will enhance the conservation of the most sensitive bat species.

About $70 \%$ of all bats species are insectivorous (Simmons 2005). The presence of insectivorous bats can be 
documented directly with mist-nets captures (Kunz \& Brock 1975, Castro-Luna et al. 2007, Castro-Arellano et al. 2009, 2010) and indirectly with ultrasonic detectors (Hayes et al. 2009, Russo \& Jones 2003, Fuentes-Montemayor et al. 2013). Echolocation calls provide an opportunity to unobtrusively survey, identify and monitor bat species (Catto 1994, de Oliveira 1998). Acoustic monitoring provides information on the level of habitat use by bats (Frick 2013), as well as can be used as a surrogate for bats relative abundance (Kalko et al. 2008, Razgour et al. 2011, Berthinussen \& Altringham 2012). Many studies have used acoustic methods to document bat activity patterns, changes in habitat use and activity of bats across different habitats (Hayes 1997, Broders 2003, Gehrt \& Chelsvig 2003, Gehrt \& Chelsvig 2004, Estrada et al. 2004, Gorresen et al. 2008, Hayes et al. 2009, Parsons \& Szewczak 2009, Russo \& Jones 2003, Fuentes-Montemayor et al. 2013, Monadjem et al. 2017). Bat activity is influenced by many factors including roost availability, weather conditions, habitat structure or bats energy requirements (Erkert 1982, Aldridge \& Rautenbach 1987, Norberg \& Rayner 1987, Lawton et al. 1998, Chung et al. 2000, Rainho et al. 2010), as well as insect prey abundance and availability (Erkert 1982, Geggie \& Fenton 1985, Avila-Flores \& Fenton 2005). Hence, information on general bat activity could be used to identify priority areas for bat conservation (Walsh \& Harri 1996, Estrada et al. 2004).

Kenya has a rich bat fauna, with more than 108 bats recorded (Patterson \& Webala 2012). The echolocation calls of more than 90 insectivorous bat species in different habitats types in Kenya have not been documented and published. These include bats in 10 families including Rhinolophidae (Horse-shoe bats, 7 spp.), Hipposideridae (Old World Leaf-nosed bats, 7 spp.), Rhinonycteridae (Trident bats, 2 spp.), Megadermatidae (False vampire bats, 2 spp.), Rhinopomatidae Mouse-tailed bats, $1 \mathrm{sp}$.), Emballonuridae (Sheath-tailed bats, 5 spp.), Nycteridae (Slit-faced bats, 7 spp.), Molossidae (Free-tailed bats, 19 spp.), Miniopteridae (Long-fingered bats, 6 spp.) and Vespertilionidae (Vesper bats, 36 spp.). While several ecological studies have been undertaken on bats in Kenya (McWilliam 1987, Webala et al. 2004, 2006, 2009, 2014, Wechuli et al. 2016, LópezBaucells et al. 2016), the absence of specific country bat call libraries in Africa which document calls of local bat species limits accurate identification of calls from acoustic detectors (Monadjem et al. 2017). Although none of the previous bat studies in Kenya were on bat activity, two (Webala et al. 2004, Wechuli et al. 2016) which concomitantly investigated bat diversity in protected areas and agricultural landscapes, showed that the farmlands had low species richness as compared to the protected areas.

Here we investigated insectivorous bat activity in the interior of ASF and in farmlands around the forest in order to understand how each habitat was used by bats. Because of the marked differences in habitat structure between the farmlands and interior of ASF, we expected variation in insectivorous bat activity in both stations. This was reinforced by data from our preliminary surveys in March 2014 , in which we found that the number of bat passes counted in each sampling station, as well as individual captures of insectivorous bats in the farmlands was larger than in each station sampled in the forest interior. Hence, we predicted that the two habitats would be used differently by insectivorous bats of different species.

\section{MATERIALS AND METHODS}

\section{Study area}

This study was undertaken in the interior of ASF and adjacent farmlands. The forest (Fig. 1) occurs in Gede town, Malindi-Kenya, $100 \mathrm{~km}$ north of Mombasa city, at latitude of $3^{\circ} 20^{\prime} \mathrm{S}$ and longitude $39^{\circ} 50^{\prime} \mathrm{E}$ (Bennun \& Njoroge 1999). The timing of seasons for the region roughly follow: JanuaryMarch (long dry season), April-June (long rain season), JulySeptember (short dry season), and October-December (short rain season) (McWilliam 1987). Generally, sun rises at $06.30 \mathrm{am}$ and sets at $18.30 \mathrm{pm}$ throughout Kenya. The forest has three discrete vegetation types namely: (i) Mixed forest (MF), 7000 ha characterized by a diversity of relatively dense, tall and of undifferentiated trees species; (ii) Brachystegia woodland (BW) c. 7636 ha dominated by Brachystegia spiciformis; and (iii) Cynometra forest (CF), c. 23,500 ha mainly dominated by Cynometra webberi tree (Kelsey \& Langton 1983). The ASF is a legally protected area, managed by Kenya Forest Service in a joint collaboration with Kenya Forest Research Institute, National Museums of Kenya and Kenya Wildlife Service. A number of narrow roads (maximum $4 \mathrm{~m}$ wide) are used to access different vegetation types in the forest. The canopy of BW (Fig. 2a) and MF (Fig. $2 \mathrm{~b}$ ) along most of the roads where sampling was undertaken was closed, while that of CF (Fig. 2c) was always open. The understory vegetation density of CF and MF was very high and bats could probably only fly in these vegetation types

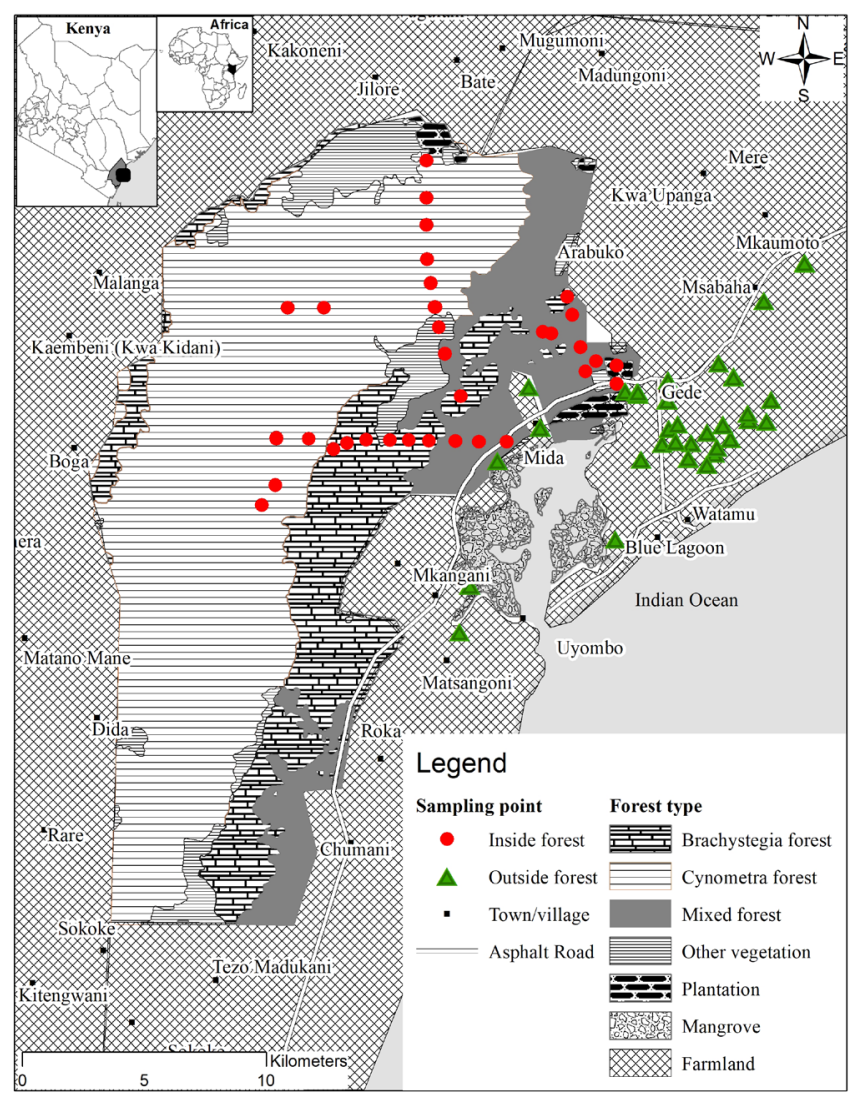

Fig. 1 - Location of the 69 sampling sites in Gede (Kenya). Red dots correspond to the sites sampled within different vegetation types in the Arabuko-Sokoke Forest (ASF) while green pyramids represent the sites located in farmlands. 
either above the canopy or below the canopy by use of existing roads or forest gaps. On the other hand the canopy and understory vegetation density of the BW was fairly open with many gaps which could be exploited by foraging or flying bats. There was no artificial electric light in the forest interior. To avoid potential biases arising from artificial light at night (Stone et al. 2012); bat activity surveys were conducted at least $200 \mathrm{~m}$ away from towns and $110 \mathrm{~m}$ from tarmac roads.

The human-modified habitats surveyed, here collectively referred as 'farmlands,' occur on the eastern part of ASF in Mtsangoni, Mkangani, Mida, Gede, Watamu, Msabaha and Mkaumoto villages (Fig. 1). The main trees found in the farms were mango (Mangifera indica), cashew nut (Anacardium occidentale), neem (Azadirachta indica) and coconut (Coco nucifera (Musila et al. 2018). We selected sampling plots in the farms by visually estimating the percentage of trees in each plot. The mango plots (MAN, Fig. 3a) had > 70\% dominance by mango trees; coconut plots (COC, Fig. 3b) >
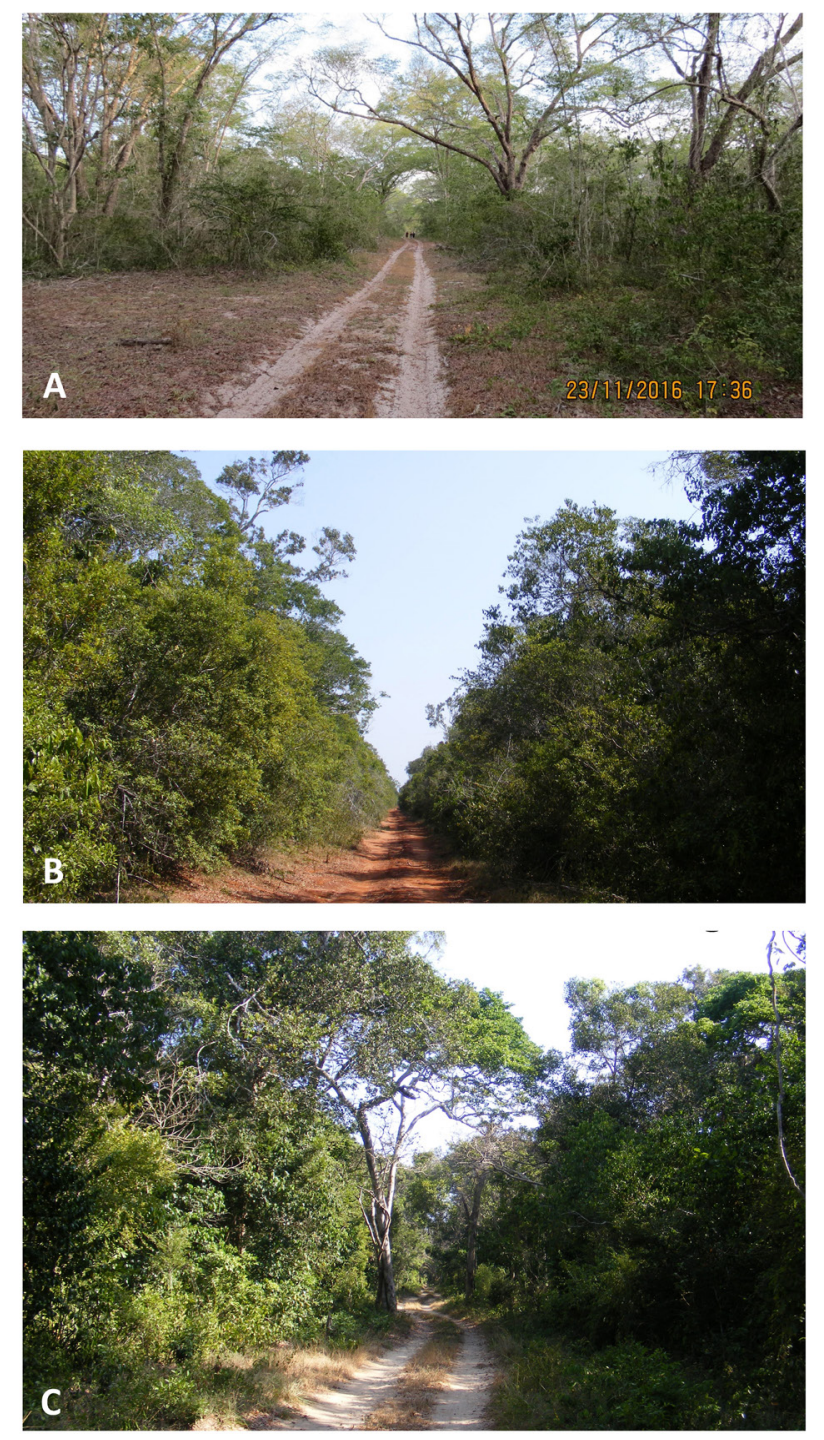

Fig. 2 - Bat activity and mist-netting stations along roads through different vegetation types in ASF. The understory of CF and MF was much closed, while the canopy of CF was open throughout and that of BW and MF closed in most of the sampling stations. A) Brachystegia woodland (BW) in ASF; B) Cynometra forest (CF) in ASF; C) Mixed forest (MF) in ASF.
$70 \%$ coconut trees; while the mixed plots (MIX, Fig. 3c) had > $50 \%, 20 \%$, and $10 \%$ of coconut trees, cashew nuts, and mango tree, respectively. Most of the trees in the farms were more than $10 \mathrm{~m}$ in height and remained evergreen throughout the year. The understory habitat of the farmlands was very open and could allow people or animals to wander about without obstruction. Farm plot size ranges from 4 to 12 ha. Some of the plots were left fallow but growing with the above mentioned trees or some plots were cultivated with maize, cowpeas and cassava. The farmlands had a number of unprotected coral limestone caves (Musila et al. 2018) and other man-made roosts (abandoned houses and others in active use by people) with a number of insectivorous and fruit bat species.

\section{Bat activity surveys}

Bat activity surveys were undertaken in six vegetation types; three within ASF (Cynometra, Brachystegia and mixed) and three in farmlands (mango, coconut, and mixed).
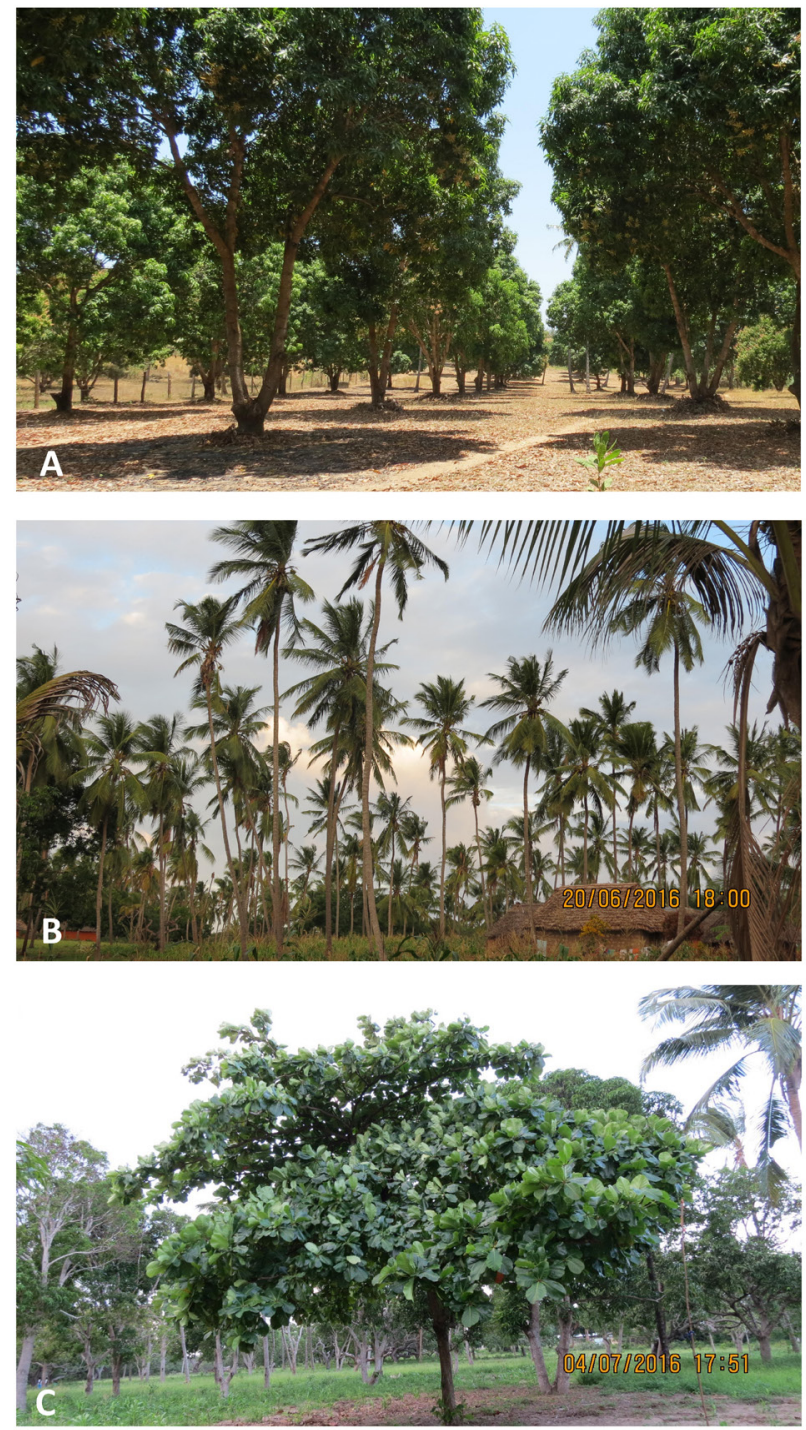

Fig. 3 - Bat activity and mist-netting stations in open areas in different vegetation types in farmlands. The understory and canopy of mango, coconut and mixed plots were open in most of the sampling stations. A) Mango (MAN) plots in farmlands; B) Cocony (COC) plots in farmlands; C) Mixed Plots (MIX) in farmlands. 
The sampling stations in each vegetation type was at least $1.5 \mathrm{~km}$ from each other in each season. We used the number of bat passes as a sampling unit for general bat activity in all surveys (Fenton 1970, Miller 2001, Frick 2013). A bat pass is a single sequence of two or more recorded echolocation calls as defined by Thomas (1988). We used Pettersson D240X ultrasound detectors (Pettersson Elektronik ABTM, Uppsala, Sweden (http://www.batsound.com/) in heterodyne mode (Estrada et al. 2004, Barros et al. 2014) to survey bat activity. The detector was always tuned to $33 \mathrm{kHz}$, and bat passes were counted along 10-minute transects at the start of each hour. The length of the transects surveyed in each station was $400 \mathrm{~m}$. Since the Pettersson D240X has bandwidth of 8 $\mathrm{kHz}$, it can detect bat species whose echolocation is within the range of $25-41 \mathrm{kHz}$. Bat passes were recorded by an observer walking on foot with the detector held in the hand (Estrada et al. 2004, Monadjem et al. 2010a). The number of passes was counted using a tally counter in each station. No survey was done during nights of heavy rainfall. About $40 \%$ of insectivorous bat species in Kenya have echolocation calls within the range we set the detector (Monadjem et al. 2010b, Happold \& Happold 2013). However, due to the unavailability of documented call libraries describing calls for local insectivorous bat species in Kenya we decided to use the Pettersson D240X ultrasound detector in heterodyne mode.

In addition to activity surveys, bats were also sampled in each of 69 stations inside ASF and farmlands using five ground-level mist-nets $(12 \times 2.5 \mathrm{~m}, 16 \mathrm{~mm}$ mesh, four shelves, Ecotone, Poland) (Castro-Luna et al. 2007, CastroArellano et al. 2009, 2010). The aim of mist-netting was to confirm the presence of detector targeted bat species both in the forest interior and farmlands, and their likelihood of being captured in mist-nets. In ASF nets were erected across existing roads which acts as potential bat flyways in the forest interior, while in the farmlands they were deployed in gaps between two trees or row of trees, or in the open areas under tall coconut trees. Bat activity and mist-netting stations in the farmlands and inside ASF were sampled alternatively, one night in the forest and the next in the farmlands. A total of 69 stations were sampled with mist-nets both in the ASF and farmlands, in six different sampling trips in between November 2014-June 2016 (Table 1). Although bat passes were not identified to species, the species captured in the mist-nets (Table 2), and whose echolocation call range was within the detector setting used, most likely accounted for most of the counted passes.

\section{Data analysis}

We measured bat activity as the number of bat passes (Russo \& Jones 2003) in each habitat and hour. We used independent samples $t$-test to test for differences in the mean number of passes between farmlands and forest interior, after log transforming the passes count data because it was not normally distributed. Kruskal-Wallis test was used to test for sampled medians of bat passes in different vegetation types in the farmlands and ASF as well as seasonal changes in bat activity. To compare seasonal changes and hourly trends in bat activity we used 11 hours (1900-0500hr) data for surveys in November 2015 (short rain season), February 2016 (dry) and November 2016 (long rains seasons) because the sampling effort was the same across seasons. All statistical analyses were undertaken using PAST (Hammer et al. 2001).

\section{RESULTS}

\section{Bat species detected or missed by the detector setting}

A total of 11 insectivorous bat species were captured in mist net surveys, which could potentially be detected by the detector set at $33 \mathrm{kHz} \pm 8 \mathrm{kHz}$ (Table 2). The largest numbers of these captures were in farmlands than in forest interior. In farmlands the largest number of capture was in coconut plots, while in the interior of ASF it was Brachystegia woodland. Two species; Scotoecus hirundo and Neoromicia tenuipinnis were captured in farmlands but not in ASF. Individuals of seven other bat species were also captured in the mist-nets in the study areas, which could not be detected since their echolocation calls range is higher or lower than the detector setting used in the survey (Table 3).

\section{Insectivorous bat activity}

A total of 14,727 passes were recorded: $71.7 \%$ in farmlands and $28.3 \%$ in ASF. The mean number of passes per night in farmlands was significantly higher $(152.9 \pm 13.2$, $\mathrm{N}=69)$ than in ASF $(60.5 \pm 4.6, \mathrm{~N}=69)(d f=68, \mathrm{t}=-8.67$, $\mathrm{P}<0.05, \mathrm{~N}=69$ ). Even though activity in coconut plots was slightly higher $(156.3 \pm 24.8, N=23)$, than in mango (153.3 \pm $19.2, \mathrm{~N}=23)$ and mixed $(148.2 \pm 24.9, \mathrm{~N}=23)$ plots (Fig. 4), there was no significant difference in the sampled medians of bat passes in the three vegetation types $(H=0.3869, d f=$ $22, \mathrm{P}=0.82)$. In ASF the highest mean bat activity per night was recorded in Brachystegia woodland $(65.2 \pm 7.2, \mathrm{~N}=23)$, followed by Mixed forest (64.9 $\pm 9.7, \mathrm{~N}=23)$ and Cynometra forest $(51.5 \pm 6.9, N=23$ ) (Fig. 4). However, there was no significant difference in the sampled medians of bat passes per night in the three vegetation types $(H=2.419, d f=22, \mathrm{P}$ $=0.03, \mathrm{~N}=69$ ).

\section{Hourly trend in bat activity}

The mean bat activity per hour in farmlands was highest at $19: 00 \mathrm{hr}(30.3 \pm 6.6, \mathrm{~N}=36)$ and lowest at 01:00hr $(8.4 \pm$ $1.3, N=36)$. In the forest interior, the mean bat activity per hour was highest at 19:00hr $(14.6 \pm 1.9, \mathrm{~N}=36)$ and lowest at $0: 00 h r(4.1 \pm 0.7, N=36)$. In general bat activity pattern in both main habitat types had two main peaks; activity peaked at 19:00hr, sharply declined to the lowest level in between 0:00hr-01:00hr and maintained a gradual increase from 02:00hr to another lower peak at 05:00hr (Fig. 5 \& 6).

\section{Seasonal trend in bat activity}

The mean bat activity per night in the wet season (123.1 $\pm 11.8, \mathrm{~N}=24$ ) was the highest, followed by short rains season $(112.8 \pm 27.2, \mathrm{~N}=24)$ and lowest in the dry season $(96.2 \pm 10.9, N=24)$. There was a significant difference in the sampled medians of bat passes per night in the three different sampling seasons $(H=6.458, d f=23, \mathrm{P}<0.04, \mathrm{~N}=$ 69). 


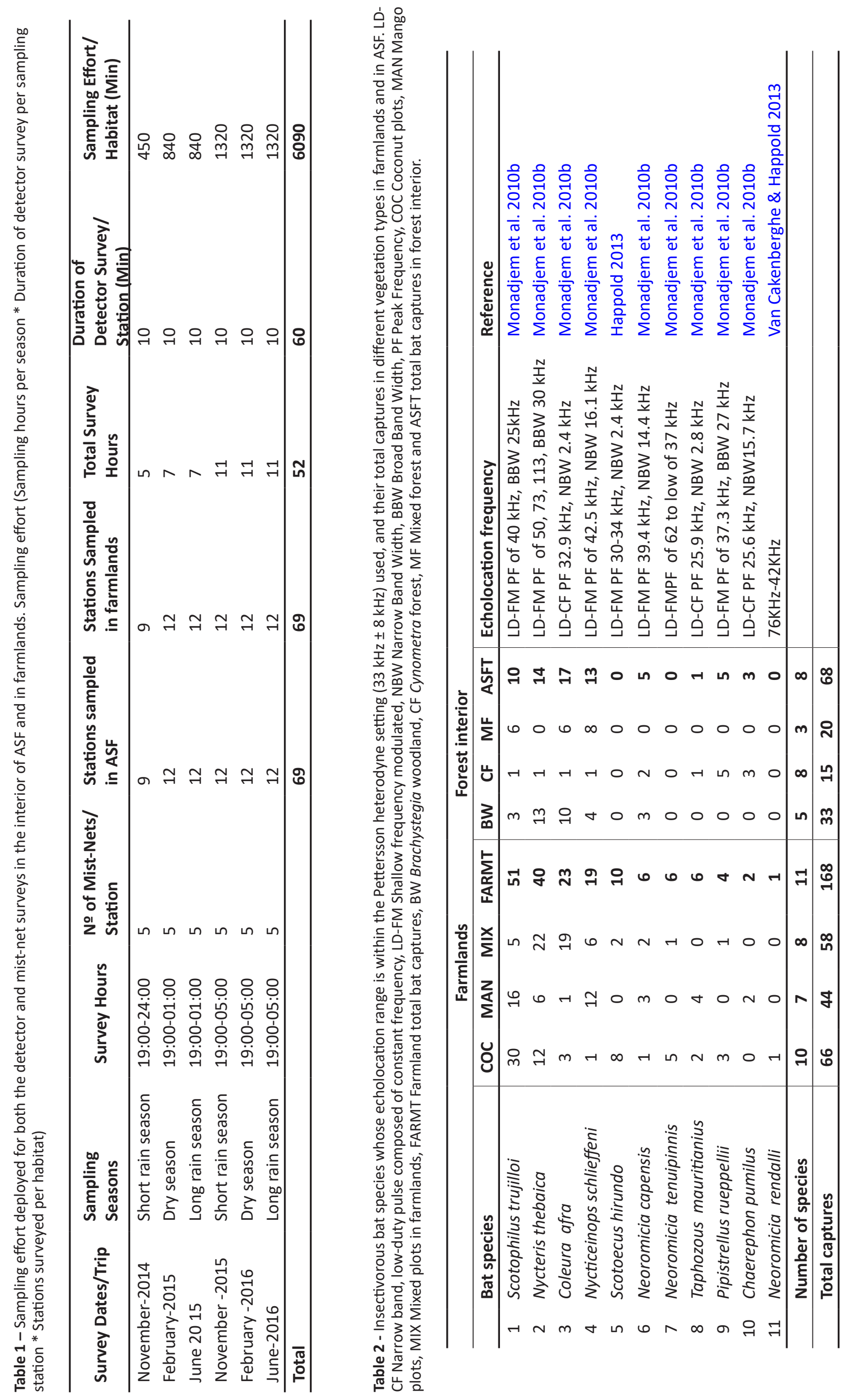


Table 3 - Insectivorous bat species occurring in different vegetation types in farmlands and in ASF which could not be detected with the Pettersson heterodyne setting $(33 \mathrm{kHz} \pm 8 \mathrm{kHz}$ ) used during the survey. LD-CF Narrow band, low-duty pulse composed of constant frequency, LD-FM Shallow frequency modulated, NBW Narrow Band Width, BBW Broad Band Width, PF Peak Frequency, COC Coconut Plots, MAN Mango plots, MIX Mixed plots in farmlands, FARMT Farmland total bat captures, BW Brachystegia woodland, CF Cynometra forest, MF Mixed forest and ASFT total bat captures in forest interior.

\begin{tabular}{|c|c|c|c|c|c|c|c|c|c|c|}
\hline \multicolumn{6}{|c|}{ Farmlands } & \multicolumn{5}{|c|}{ Forest interior } \\
\hline Bat species & $\mathrm{COC}$ & MAN & MIX & FARMT & BW & CF & MF & ASFT & Echolocation freq. & References \\
\hline Cardioderma cor & 209 & 141 & 254 & 604 & 2 & 0 & 0 & 2 & $56.7 \pm 11 \mathrm{kHz}$ & Taylor et al. 2005 \\
\hline $\begin{array}{l}\text { Macronycteris } \\
\text { vittata }\end{array}$ & 6 & 17 & 13 & 36 & 6 & 7 & 7 & 20 & HD-FC PF 61 kHz, & Monadjem et al. 2010b \\
\hline $\begin{array}{l}\text { Hipposideros } \\
\text { caffer }\end{array}$ & 8 & 2 & 11 & 21 & 0 & 13 & 0 & 13 & $\begin{array}{l}\text { HD-CF PF } 142.3 \mathrm{kHz} \text {, } \\
\text { NBW } 8.4 \mathrm{kHz}\end{array}$ & Monadjem et al. 2010b \\
\hline $\begin{array}{l}\text { Rhinolophus } \\
\text { deckenii }\end{array}$ & 5 & 8 & 15 & 28 & 1 & 8 & 1 & 10 & $\mathrm{HD}-\mathrm{FC}$ PF $72 \mathrm{kHz}$ & Monadjem et al. $2010 \mathrm{~b}$ \\
\hline Neoromicia nana & 0 & 10 & 2 & 12 & 4 & 14 & 0 & 18 & $\begin{array}{l}\text { LD-FM PF } 69 \mathrm{kHz} \\
\text { BBW } 17.8 \mathrm{kHz}\end{array}$ & Monadjem et al. 2010b \\
\hline $\begin{array}{l}\text { Otomops } \\
\text { harrisoni }\end{array}$ & 10 & 0 & 1 & 11 & 0 & 0 & 0 & 0 & $10-12 \mathrm{kHz}$ & Yalden \& Happold 2013 \\
\hline Triaenops afer & 4 & 1 & 0 & 5 & 0 & 0 & 0 & 0 & $77-80 \mathrm{kHz}$ & Monadjem et al. 2010 \\
\hline Totals & 242 & 179 & 296 & 717 & 13 & 42 & 8 & 63 & & \\
\hline
\end{tabular}

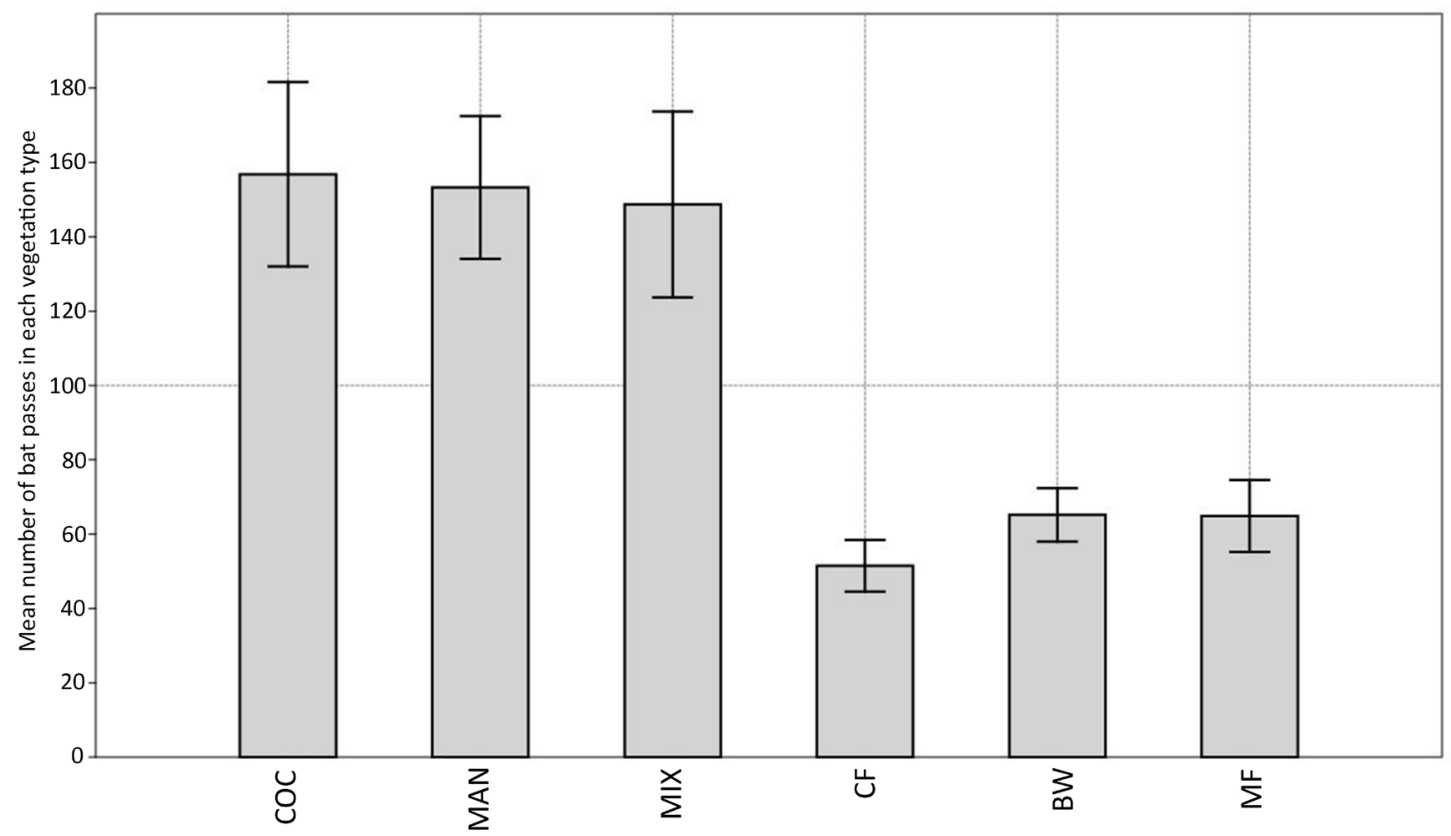

Fig. 4 - The mean number of bat passes recorded in each vegetation type in farmlands (COC-Coconut, MAN-Mango, MIXMixed plots) and in ASF (CF-Cynometra forest, BW-Brachystegia woodland, MF-Mixed forest).

\section{DISCUSSION}

Our study investigated insectivorous bat activity in the less disturbed interior of ASF and adjacent highly disturbed farmlands. The farmlands had higher bat activity than the forest interior. In addition, more than twice the number of bats potentially targeted by the detector setting was captured in farmlands than in ASF. Our results of activity surveys are consistent with findings by Estrada et al. (2004), who found higher bat activity in villages, along live fences and citrus farms, than in continuous forest in tropical rainforest in southeastern Veracruz, Mexico. Although high levels of bat activity appear to indicate areas which are important to bats and those they use heavily (Adams et al. 2015), and the number of passes counted is probably correlated to the number of individuals present (Wickramasinghe et al. 2003), it is not possible to quantify the exact number of individuals present in a given station since a detector can record the same individual more than once (Frick 2013). Therefore, despite the higher bat activity and number captures detected in farmlands than in the forest interior, the results of our study should be interpreted with caution. 


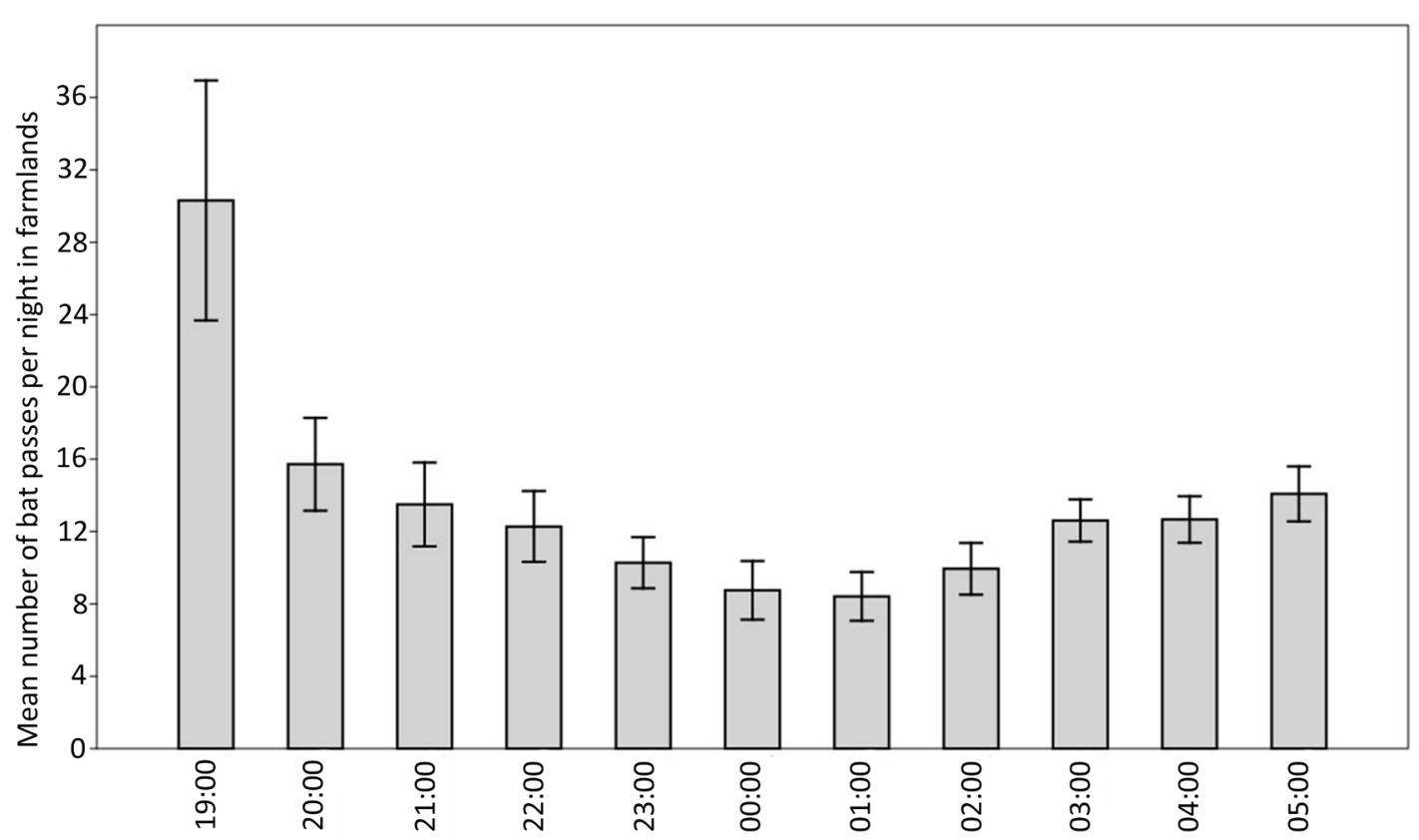

Fig. 5 -The mean number of bat passes per night in farmlands (November 2015, February 2016 and June 2016).

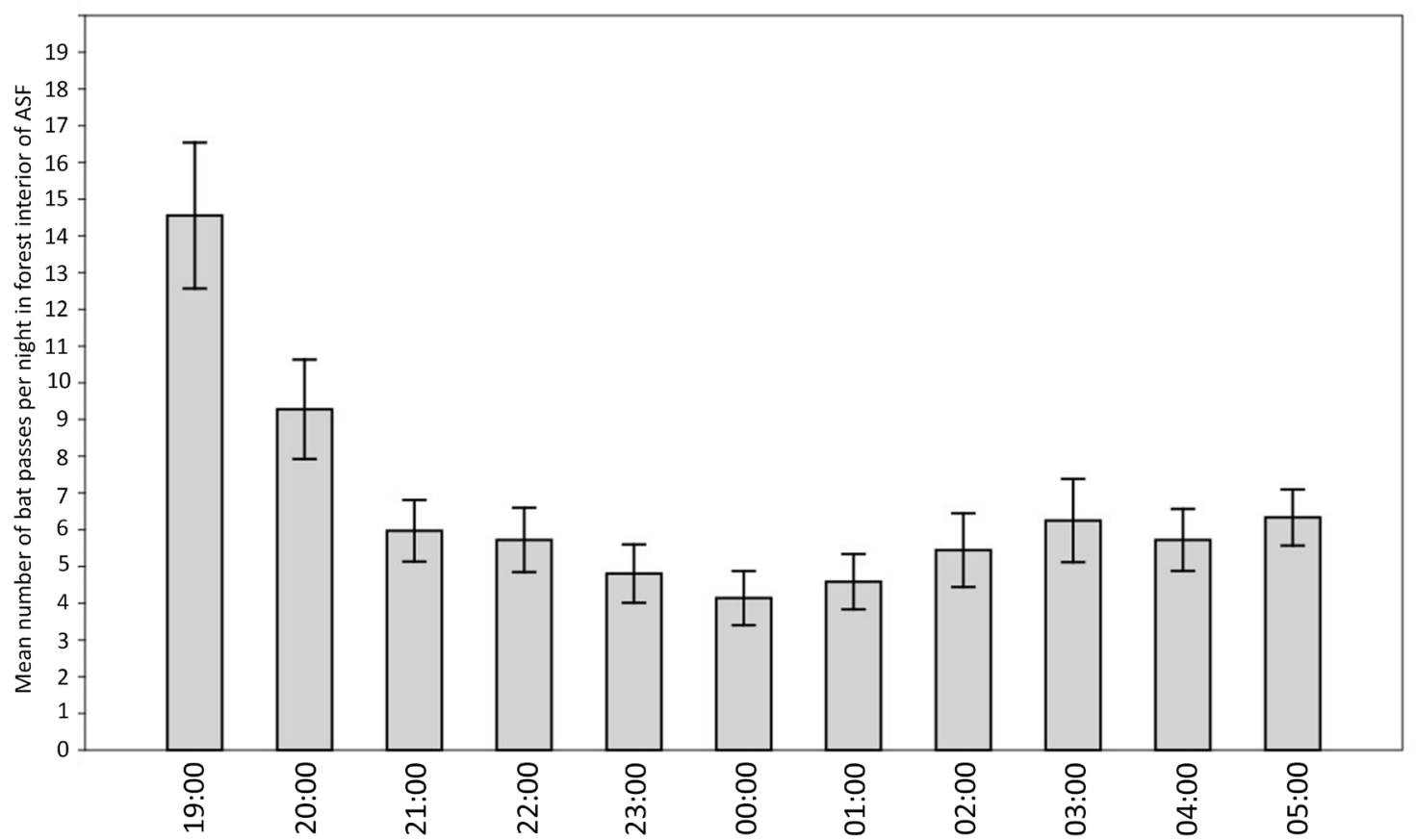

Fig. 6 - The mean number of bat passes per night in forest interior of ASF (November 2015, February 2016 and June 2016).

The inability to identify the calls to species made it impossible to pinpoint the bat species using these habitats. We used only one frequency setting $(33 \mathrm{kHz})$ throughout the 69 sampling stations, which limited the number of passes we counted at each station because some species like those in genus Hipposideros call at higher frequencies (Happold \& Happold 2013). These species are mostly forest-dwelling species (better adapted to the forest interiors), biasing our sampling design towards open-space foragers. However, eleven species (Scotophilus trujilloi, Nycteris thebaica, Coleura afra, Nycticeinops schlieffeni, Scotoecus hirundo,
Neoromicia capensis, Neoromicia tenuipinnis, Taphozous mauritanius, Pipistrellus rueppellii and Chaerephon pumilus, Neoromicia rendalli) were confirmed in mist-net surveys to occur in the study areas and probably contributed significantly to the calls we counted. Insectivorous bats also modify their echolocation calls throughout their flight based on the habitat structure and whether involved in foraging or commuting activity. For instance, bats in cluttered habitat emit quieter echolocation calls, which can reduce detection rate and make species identification from ultrasonic recordings more difficult (Schnitzler \& Kalko 2001, Russ 
2003). The result is a false absence, with present species being undetected (MacKenzie 2005), and consequently counting a reduced number of echolocation calls.

The differences in vegetation clutter across habitats can also affect bat activity and exploitation of insect prey available. Increasing clutter can make foraging more complicated and increase the energetic coast of flight (Aldridge \& Rautenbach 1987, Norberg \& Rayner 1987). Vegetation clutter can inhibit flight for some bat species (Brigham et al. 1997). The negative influence of clutter is likely related to difficulties associated with tracking prey while simultaneously monitoring location of obstacles (Simmons et al. 1979) rather than decreased prey abundance (Bender et al. 2015). Therefore, the high density of understory vegetation in the forest interior probably constrained some bat species exploitation of this habitat, probably explaining the low captures of detector targeted bats in ASF (68) than in farmlands (168). High understory and canopy vegetation densities may also probably constraint detection of calls of some bat species especially those with low detection distances, because the vegetation clutter may act as an obstacle against sound movement in the environment. For example, calls of some species recorded in this survey such as those of S. trujilloi (with detection distance of 12.5-15 m), N. schlieffeni $(15.0 \mathrm{~m})$ and Scotoecus hirundo, C. pumilus (12-20 m) (Monadjem et al. 2017), may probably be easily detected in more open farmlands vegetation types with reduced sound movement restrictions than in more closed ASF habitat. This probably may explain the slightly higher activity of bats and larger captures of detector targeted bats in the more open coconut plots and Brachystegia woodland, than in the other vegetation types in our study areas. In addition, some bats in family molossid and genus Taphozous are fast fliers and hawk insects in high altitude above the forest canopy (Norberg \& Rayner 1987, Duffy et al. 2000, MacSwiney et al. 2008), and detection of their calls would be impaired when sampling by walking on the ground surrounded by tall trees and under closed tree canopies, like it was the case in the interior of ASF. In addition, mist-nets provide a biased sample of bat species assemblages (Murray et al. 1999, Sampaio et al. 2003, MacSwiney et al. 2007). These factors may have contributed to the lower bat activity recorded in the forest interior as well as the low number of bats captured in mist-nets in this habitat. Future research should therefore, build a reference echolocation calls library of insectivorous bat species in the study area (O'Farrell \& Gannon 1999), and then use this information in bat acoustic activity surveys. This method will improve our understanding about specific species using each habitat, and changes of their activity with time and seasons.

Temporal trends in bat activity both inside ASF and farmlands showed the same pattern; being highest at 19:00hr, significantly declined to lowest in between 0:00hr01:00hr, and then increased to a lower peak at 05:00hr. Our results of two bat activity peaks, are conistent with activity of Neoromicia nana in the logged and unlogged forest section of Kibale National Park, which was most active in the first five hours after sunset after which activity declined rapidly after midnight until sampling ended at 01:00 hrs (Monadjem et al. 2010a). The pattern we observed in our study, is typical of many species of insectivorous bats (Kunz
1973, Erker 1982, Rautenbach et al. 1988, Taylor \& O’Neill 1988, Maier 1992, Rydell et al. 1996, Meyer et al. 2004) where bats are active in foraging after leaving their day roost, reduce activity when they return to roosts again in the middle of the night, eventually followed by a final bout of foraging and commuting activity before returning to their day roosts (Kunz 1974, Kunz et al. 1995). Bat activity was highest in the wet than dry season, probably suggesting increased foraging or commuting activity of bats in search of insect preys in order to increase their breeding success. Bats synchronize reproduction with periods of high food availability (Bronson 1985), because of high energy demand and potential risks associated with breeding (Studier et al. 1973, Kurta et al. 1989). Future studies should investigate the breeding patterns of bats around the study area and determine whether it is influenced by seasonal changes in food (invertebrates) availability and rainfall patterns.

The indigenous coastal vegetation in ASF had been completely destroyed in the areas around this forest and had been replaced with agricultural farms, human settlements and cultivated exotic trees. However, our farmlands were still being used by some bat species either for commuting through or foraging, probably because of the large number of cultivated trees in this open-space habitat. The farmlands also had larger number of bats (which could not be recorded with the detector settings) (717) than the forest interior (63), which emphasizes the value of this habitat for bat conservation. Farmlands biodiversity is probably greatly enhanced by the presence of isolated big trees (Fischer et al. 2010). The farmlands in Gede, were not bare but had many cultivated exotic mangos, cashew nuts, neems and coconut trees which probably provided suitable foraging and roosting habitats for the bats. Foraging activity of bats is often higher near trees in open areas and along edges (Lumsden \& Bennet 2005, Downs \& Racey 2006, Law \& Chidel 2006). Thus, human modified habitats that incorporate large trees on farms might have reduced effect on bat activity and abundance (Williams-Guillén et al. 2016) than in bare open areas. Some research has also shown that habitat disturbance does not affect activity of some bat species, that are well-adapted to anthropic environments. For example, Fenton et al. (1998) found that the common vespertilionid and molossid bats, those feeding on airborne insects, were also found in sites in savanna woodlands in Zimbabwe where the tree canopy had virtually been eliminated. Insectivorous bats are highly mobile (McCracken et al. 2012), and forage over large areas in a single night (Treitler et al. 2016). Thus, the high bat activity in the farmlands in our study area may indicate certain conservation value of this habitat for some bat species, probably due to abundance of insect prey. In addition to trees, a number of limestone caves with insectivorous bats occurred in farmlands than in the forest. Some of these caves like Alibaba and Kaboga had large bat populations of multiple species (Musila et al. 2018). The simultaneous emergence of bats from these roosts, to forage in the evening and their return at dawn, probably increased bat activity in the farmlands. However, the future of these caves is uncertain, because they are unprotected and occurred in private land. Future research should shed more light on the role of farmlands trees in Gede in sustaining bats in this habitat. 


\section{CONCLUSION}

In conclusion, although farmlands had higher bat activity and captures than ASF, future research addressing limitations of our methods would provide a more accurate understanding about bats habitat use of these two main habitats. Human-modified habitat like farmlands, human settlements and other mosaics are rapidly increasing due to increasing global human population. The farmlands in Gede, had completely lost the coastal indigenous vegetation found in ASF, and had been replaced with cultivated fruit trees and food crop farms. However, some bat species still use this habitat which emphasizes the need for more research in agricultural areas in Africa in order to understand their role for conservation of bats in the continent. Furthermore, it would be important to continue to encourage the local farmers around Gede, to maintain the existing orchard trees or even to cultivate more trees in their farms, in order to sustain vegetation cover in the farmlands which may be suitable for bats conservation.

\section{ACKNOWLEDGEMENTS}

We are very grateful to farmer owners in the study area for allowing us to access their farm and sample bats at night. We thank Simon Kajengo our community field guide and Aaron Musyoka, driver and mechanic during data collection. We are very grateful to Lars Pettersson, founder of Pettersson Elektronik, for donating three Pettersson D240X to our project; and to Jens Rydell for bringing them to Kenya and training us how to use them. We are very grateful to British Ecological Society (Ecologists in Africa grant) Number 4632-5670 and Kunming Institute of Zoology, Mammal Ecology and Evolution Group for funding. Bat Conservation International also provided 30 mist nets used in the survey. The Kenya Forest Service assisted the research team by waiving the camping fees at ASF during the study. We also thank two anonymous reviewers who assisted in reviewing our manuscript before it was accepted for publication.

\section{REFERENCES}

ADAMS, A.M., MCGUIRE, L.P., HOOTON, L.A., \& FENTON, M.B. (2015). How high is high? using percentile thresholds to identify peak bat activity. Canadian Journal of Zoology, 93:307-313. https://doi.org/10.1139/cjz-2014-0230

ALDRIDGE, H.D., \& RAUTENBACH, I.L. (1987). Morphology, echolocation and resource partitioning in insectivorous bats. Journal of Animal Ecology, 56(3):763-778. https:// doi.org/10.2307/4947

AVILA-FLORES, R., \& FENTON, B. (2005). Use of spatial features by foraging insectivorous bats in a large urban landscape. Journal of Mammalogy, 86(6): 1193-1204. https://doi.org/10.1644/04-MAMM-A-085R1.1

BARROS, M.A.S., PESSOA, D.M.A., \& RUI, A.M. (2014). Habitat use and seasonal activity of insectivorous bats (Mammalia: Chiroptera) in the grasslands of southern Brazil. Zoologia, 31: 153-161.
BENDER, M.J., CASTLEBERRY, S.B., MILLER, D.A., \& WIDLEY, T.B. (2015). Site occupancy of foraging bats on landscapes of managed pine forest. Forest Ecology and Management, 336:1-10. https://doi.org/10.1016/j. foreco.2014.10.004

BENNUN, L.A., \& NJOROGE, P. (1999). Important Bird Areas in Kenya. ed.: Nature Kenya, East Africa Natural History Society, Nairobi, Kenya. 318 pp.

BERTHINUSSEN, A., \& ALTRINGHAM, J. (2012). The effect of a major road on bat activity and diversity. Journal of Applied Ecology, 49(1): 82-89. https://doi.org/10.1111/ j.1365-2664.2011.02068.x

BOYLES, J.G., CRYAN, P.M., MCCRACKEN, G.F., \& KUNZ, T.H. (2011). Economic importance of bats in agriculture. Science, 332(6025):41-42. https://doi.org/10.1126/ science. 1201366

BRADSHAW, C.J.A., SODHI, N.S. \& BROOK, B.W. (2009). Tropical turmoil: a biodiversity tragedy in progress. Frontiers in Ecology and the Environment, 7(2):79-87. https://doi.org/10.1890/070193

BRIGHAM, R.M., GRINDAL, S.D., FIRMAN, M.C., \& MORISSETTE, J.L. (1997). The influence of structural clutter on activity patterns of insectivorous bats. Canadian Journal of Zoology, 75(1): 31-136. https://doi. org/10.1139/z97-017

BRODERS, H. (2003). Another quantitative measure of bat species activity and sampling intensity considerations for the design of ultrasonic monitoring studies. Acta Chiropterologica, 5(2): 235-241. https://doi. org/10.3161/001.005.0206

BRONSON, F.H. (1985). Mammalian reproduction: an ecological perspective. Biology of Reproduction, 32(1):126. https://doi.org/10.1095/biolreprod32.1.1

BROOKS, T.M., MITTERMEIER, R.A., MITTERMEIER, C.G., DE FONSECA, G.A.B., RYLANDS, A.B., KONSTANT, W.R., FLICK, P., PILGRIM, J., OLDFIELD, S., MAGIN, G. \& HILTONTAYLOR, C. (2002). Habitat loss and extinction in the hotspots of biodiversity. Conservation Biology, 16(4):909923. https://doi.org/10.1046/j.1523-1739.2002.00530.x

CASTRO-ARELLANO, I., PRESLEY, S.J., WILLIG, M.R., WUNDERLE, J.M., \& SALDANHA, L.N. (2009). Reducedimpact logging and temporal activity of understorey bats in lowland Amazonia. Biological Conservation, 142(10):2131-2139. https://doi.org/10.1016/j. biocon.2009.04.013

CASTRO-ARELLANO, I., LACHER, T.E., WILLIG, M.R., \& RANGE, T.F. (2010). Assessment of assemblage-wide temporal niche segregation using null models. Methods in Ecology and Evolution, 1(3):311-318. https://doi.org/10.1111/ j.2041-210X.2010.00031.x 
CASTRO-LUNA, A.A., SOSA, V.J., \& CASTILLOS-CAMPOS, G. (2007). Bat diversity and abundance associated with the degree of secondary succession in a tropical forest mosaic in south-eastern Mexico. Animal Conservation, 10(2): 219-228. https://doi.org/10.1111/j.14691795.2007.00097.x

CATTO, C.M.C. (1994). Bat Detector Manual. The Bat Conservation Trust. London, United Kingdom.

de OLIVEIRA, M.C. (1998). Anabat system practical guide. Department of Natural Resources-University of Queensland. Queensland, Australia.

DIXON, M.D. (2012). Relationship between land cover and insectivorous bat activity in an urban landscape. Urban Ecosystem, 15: 683-695. https://doi.org/10.1007/ s11252-011-0219-y

DOWNS, N.C., \& RACEY, P.A. (2006). The use by bats of habitat features in mixed farmland in Scotland. Acta Chiropterologica, 8(1):169-185. https://doi. org/10.3161/150811006777070893

DUFFY, A.M., LUMSDEN, L.F., CADDLE, C.R., CHICK, R.R., \& NEWELL, G.R. (2000). The efficacy of AnaBat ultrasonic detectors and harp traps for surveying microchiropterans in south-eastern Australia. Acta Chiropterologica, 2(2):127-144.

ERKERT, H.G. (1982). Ecological Aspects of Bat Activity Rhythms. In: Ecology of Bats. ed. Springer US. Boston, USA. p. 201-242. https://doi.org/10.1007/978-1-46133421-7_5

ESTRADA, A., JIMÉNEZ, C., RIVERA, A., \& FUENTES, E. (2004). General bat activity measured with an ultrasound detector in a fragmented tropical landscape in Los Tuxtlas, Mexico. Animal Biodiversity and Conservation, 27(2):5-13.

FAOSTAT. (2011, April 18). Food and Agriculture Organization of the United Nations.

FENTON, M.B. (1970). A technique for monitoring bat activity with results obtained from different environments in southern Ontario. Canadian Journal of Zoology, 48(4):847-851. https://doi.org/10.1139/z70-148

FENTON, B.M., CUMMING, D.H.M., RAUTENBACH, I.L., CUMMING, G.S., CUMMING, M.S., FORD, G., TAYLOR, R.D., DUNLOP, J., HOVORKA, M.D., JOHNSTON, D.S., PORTFORS, C.V., KALCOUNIS, M.C., \& MAHLANGA, Z. (1998). Bats and the loss of tree canopy in African woodlands. Conservation Biology. 12(2):399-407. https://doi.org/10.1111/j.1523-1739.1998.96376.x

FISCHER, J., ZERGER, A., GIBBONS, P., \& LAW, B.S. (2010). Tree decline and the future of Australian farmland biodiversity. P. Natl. Acad. Sci. USA, 107(45): 1959719602. https://doi.org/10.1073/pnas.1008476107

FOLEY, J.A., DEFRIES, R., ASNER, G.P., BARFORD, C., BONAN, G., CARPENTER, S.R., CHAPIN, F.S., COE, M.T., DAILY, G.C., GIBBS, H., HELKOWSKI, J.H., HOLLOWAY, T., HOWARD, E.A., KUCHARIK, C.J., MONFREDA, C., PATZ, J.A., PRENTICE,
C., RAMANKUTTY, N., \& SNYDER. P.K. (2005). Global consequences of land use. Science, 309(57349):570574. https://doi.org/10.1126/science.1111772

FRICK, W.F. (2013). Acousticmonitoring of bats, considerations of options for long-term monitoring. Therya, 4(1):69-78. https://doi.org/10.12933/therya-13-109

FUENTES-MONTEMAYOR, E., GOULSON, D., CAVIN, L., WALLACE, J.M., \& PARK, K.J. (2013). Fragmented woodlands in agricultural landscapes: The influence of woodland character and landscape context on bats and their insect prey. Agriculture, Ecosystems and Environment, 172: 6-15. https://doi.org/10.1016/j. agee.2013.03.019

GASTON, K.J., BLACKBURN, T.M., \& GOLDEWIJK, K.K. (2003). Habitat conversion and global avian biodiversity loss. $P$. R. Soc. Lond.B Bio, 270(1521):1293-1300. https://doi. org/10.1098/rspb.2002.2303

GEGGIE, J.F., \& FENTON, M.B. (1985). A comparison of foraging by Eptesicus fuscus (Chiroptera: Vespertilionidae) in urban and rural environments. Canadian Journal of Zoology, 63(2): 263-266. https://doi.org/10.1139/z85040

GEHRT, S.D., \& CHELSVIG, J.E. (2003). Bat activity in an urban landscape: patterns at the landscape and microhabitat scale. Ecological Applications, 13(4):939-950. https:// doi.org/10.1890/02-5188

GEHRT, S.D., \& CHELSVIG, J.E. (2004). Species-specific patterns of bat activity in an urban landscape. Ecological Applications, 14(2):625-635. https://doi. org/10.1890/03-5013

GORRESEN, P., MILES, A., TODD, C., BONACCORSO, F., \& WELLER, T. (2008). Assessing bat detectability and occupancy with multiple automated echolocation detectors. Journal of Mammalogy, 89(1):11-17. https:// doi.org/10.1644/07-MAMM-A-022.1

HAMMER, Ø., HARPER, D.A.T., \& RYAN, P.D. (2001). PAST: paleontological statistics software package for education and data analysis. Palaeontol Electron, 4: 9.

HAPPOLD, M. (2013). Scotoecus hirundo Dark-winged Lesser House Bat. In: Mammals of Africa (Hedgehogs, Shrews and Bats). Ed.: Bloomsbury Publishing, London, United Kingdom, pp. 669-671.

HAPPOLD, M., \& HAPPOLD, D.C.D. (2013). Mammals of Africa: Hedgehogs, Shrews and Bats. Ed.: Bloomsbury Publishing, London, United Kingdom. 800 pp.

HAYES, J.P. (1997). Temporal variation in activity of bats and the design of echolocation monitoring studies. Journal Mammalogy, 79(2):514-524. https://doi. org/10.2307/1382902

HAYES, J.P., OBER, H.K., \& SHERWIN, R.E. (2009). Survey and monitoring of bats. In: The ecological and behavioral methods for the study of bats. Ed.: The John Hopkins University Press, Baltimore, Maryland,USA. pp. 112-132. 
JOHNSON, J.B., GATES, J.E., \& FORD, W.M. (2008). Distribution and activity of bats at local and landscape scales within a rural-urban gradient. Urban Ecosystems, 11(2):227-242. https://doi.org/10.1007/s11252-008-0055-x

JONES, G., JACOBS, D.S., KUNZ, T.H., WILLIG, M.R., \& RACEY, P.A. (2009). Carpe noctem: the importance of bats as bioindicators. Endangered Species Research, 8(1-2):93115. https://doi.org/10.3354/esr00182

KALKO, E.K.V., \& CONDON, M.A. (1998). Echolocation, olfactionand fruit display: how bats find fruit of flagellichorous cucurbits. Functional Ecology, 12(3):364372. https://doi.org/10.1046/j.1365-2435.1998.00198.x

KALKO, E.K.V., VILLEGAS, S.E., SCHMIDT, M., WEGMANN, M., \& MEYER, C.F.J. (2008). Flying high-assessing the use of the aerosphere by bats. Integrative and Comparative Biology, 48(1):60-73. https://doi.org/10.1093/icb/ icn030

KELM, D.H., WIESNER, K., \& HELVERSEN, O. (2008). Effects of artificial roosts for frugivorous bats on seed dispersal in a Neotropical forest pasture mosaic. Conservation Biology, 22(3):733-741. https://doi.org/10.1111/j.15231739.2008.00925.x

KELSEY, M.G., \& LANGTON, T.E.S. (1983). The Conservation of the Arabuko-Sokoke Forest, Kenya. ICBP Technical report. Cambridge, United Kingdom.

KUNZ, T.H. (1973). Resource utilization: temporal and spatial components of bat activity in central lowa. Journal Mammalogy, 54(1):14-32. https://doi. org/10.2307/1378869

KUNZ, T.H. (1974). Feeding ecology of a temperate insectivorous bat (Myotis velifer). Ecology, 55(4):693-711. https://doi.org/10.2307/1934408

KUNZ, T.H., \& BROCK, C.E. (1975). Comparison of mist-nets and ultrasonic device detectors for monitoring flight activity of bats. Journal of Mammalogy, 56(4):907-911. https://doi.org/10.2307/13796624

KUNZ, T.H., \& PIERSON, E.D. (1994). Bats of the world: an introduction. In: Walker's Bats of the World. Ed.: The John Hopkins University Press, Baltimore, Maryland,USA, pp. 1-46.

KUNZ, T.H., WHITAKER, J.O. JR, \& WADA-ROLL, M.D. (1995). Dietary energetics of the insectivorous Mexican freetailed bat (Tadarida braziliensis) during pregnancy and lactation. Oecologia, 101(4): 407-415. https://doi. org/10.1007/bf00329419

KUNZ, T.H., BRAUN DE TORREZ, E., BAUER, D., LOBOVA, T., \& FLEMING, T.H. (2011). Ecosystem services provided by bats. Ann. NY. Acad. Sci., 1223(1):1-38. https://doi. org/10.1111/j.1749-6632.2011.06004.x

KURTA, A., BELL, G.P., NAGY, K.A., \& KUNZ, T.H. (1989). Energetic of pregnancy and lactation in free-ranging little brown bats (Myotis lucifugus). Physiological Zoology, 62(3): 804-818. https://doi.org/10.1086/ physzool.62.3.30157928
LAW, B.S., \& CHIDEL, M. (2006). Eucalypt plantings on farms: Use by insectivorous bats in south-eastern Australia. Biological Conservation, 133(2):236-249. https://doi. org/10.1016/j.biocon.2006.06.016

LAWTON, J.H., BIGNELL, D.E., BOLTON, B., BLOEMERS, G.F., EGGLETON, P., HAMMOND, P.M., HODDA, M., HOLT, R.D., LARSEN ,T.B., MAWSLEY, N.A., STORK, N.E., SRIVASTAVA, D.S., \& WATT, A.D. (1998). Biodiversity inventories, indicator taxa and effects of habitat modification in tropical forest. Nature, 391:72-76. https://doi. org/10.1038/34166

LÓPEZ-BAUCELLS, A., ROCHA, R., WEBALA, P.W., NAIR, A., UUSITALO, R., SIRONEN, T., \& FORBES, K.M. (2016). Rapid assessment of bat diversity in the Taita Hills Afromontane cloud forests, southeastern Kenya. Barbastella, 9:1-10. https://doi.org/10.14709/BarbJ.9.1.2016.04

LUMSDEN, L.F., \& BENNETT, A.F. (2005). Scattered trees in rural landscapes: foraging habitat for insectivorous bats in south-eastern Australia. Biological Conservation, 122(2):205-222. https://doi.org/10.1016/j. biocon.2004.07.006

MACKENZIE, D.I. (2005). What are the issues with presence-absence data for wildlife managers? Journal of Wildlife Management, 69(3):849-860. https://doi. org/10.2193/0022-541X(2005)069[0849:WATIWP]2.0. $\mathrm{CO} ; 2$

MACSWINEY, M.C., VILCHIS, P., CLARKE, F.M., \& RACEY, P.A. (2007). The importance of cenotes in conserving bat assemblages in the Yucatán, Mexico. Biological Conservation, 136(4):499-509. https://doi. org/10.1016/j.biocon.2006.12.021

MACSWINEY, G., CRISTINA, M., CLARKE, F.M., \& RACEY, P.A. (2008). What you see is not what you get: the role of ultrasonic detectors in increasing inventory completeness in Neotropical bat assemblages. Journal of Applied Ecology, 45(5):1364-1371. https://doi. org/10.1111/j.1365-2664.2008.01531.x

MAIER, C. (1992). Activity patterns of pipistrelle bats (Pipistrellus pipistrellus) in Oxfordshire. Journal of Zoology, 228(1):69-80. https://doi. org/10.1111/j.1469-7998.1992.tb04433.x

MCCRACKEN, G.F., WESTBROOK, J.K., BROWN, V.A., ELDRIDGE, M., FEDERICO, P., \& KUNZ, T.H. (2012). Bats track and exploit changes in insect pest populations. PLoS One, 7(8):e43839. https://doi.org/10.1371/journal. pone.0043839

McWILLIAM, A.N. (1987). Territorial and pair behaviour of the African false vampire bat, Cardioderma cor (Chiroptera: Megadermatidae) in coastal Kenya. Journal of Zoology, 213(2):243-252. https://doi. org/10.1111/j.1469-7998.1987.tb03700.x 
MEDELLIN, R. A., \& GAONA, O. (1999). Seed Dispersal by Bats and Birds in Forest and Disturbed Habitats of Chiapas, Mexico 1. Biotropica, 31(3): 478-485. https:// doi.org/10.1111/j.1744-7429.1999.tb00390.x

MEYER, C.F.J., SCHWARZ, C.J., \& FAHR, J. (2004). Activity patterns and habitat preferences of insectivorous bats in a West African forest-savanna mosaic. Journal of Tropical Ecology, 20(4):397-407. https://doi.org/10.1017/ S0266467404001373

MILLER, B.W. (2001). A method for determining relative activity of free flying bats using a new activity index for acoustic monitoring. Acta chiropterologica, 3(1):93-105.

MILLER, J.R., SNYDER, S.A., SKIBBE, A.M., \& HAIGHT, R.G. (2009). Prioritizing conservation targets in a rapidly urbanizing landscape. Landscape and Urban Planning, 93(2):123-131. https://doi.org/10.1016/j. landurbplan.2009.06.011.

MONADJEM, A., ELLSTROM, M., MALDONALDO, C., \& FASEL, N. (2010a). The activity of an insectivorous bat Neoromicia nana on tracks in logged and unlogged forest in tropical Africa. African Journal of Ecology, 48(4):1083-1091. https://doi.org/10.1111/j.1365-2028.2010.01219.x

MONADJEM, A., TAYLOR, P.J., COTTERILL, W., \& SCHOEMAN, M. (2010b). Bats of southern and central Africa: a biogeographic and taxonomic synthesis. Ed.: Wits University Press, Johannesburg, South Africa. 596 pp.

MONADJEM, A., SHAPIRO, J.T., MTSETFWA, F., RESIDE, A.E., \& MCCLEERY, R.A. (2017). Acoustic call library and detection distances for bats of Swaziland. Acta Chiropterologica, 19:175-187. http://dx.doi.org/10.3161 /15081109ACC2017.19.1.014

MUSILA, S., PROKOP, P., \& GICHUKI,G. (2018). knowledge and perceptions of, and attitudes to, bats by people living around Arabuko-Sokoke Forest, Malindi-Kenya. Anthrozoös, 31(2):247-262. https://doi.org/10.1080/08 927936.2018.1434065

MURRAY, K.L., RITZKE, E.R.B., ADLEY, B.M.H., \& ROBBINS, L.W. (1999). Surveying bat communities: a comparison between mist nets and AnaBat II bat detector system. Acta Chiropterologica, 1:105-112.

NORBERG, U.M., \& RAYNER, J.M.V. (1987). Ecological morphology and flight in bats (Mammalia; Chiroptera): Wing adaptations, flight performance, foraging strategy and echolocation. Philos. T. Roy. Soc. B B., 316(1179): 335-427. https://doi.org/10.1098/rstb.1987.0030

O'FARRELL, M.J., \& GANNON, W.L. (1999). A comparison of acoustics versus capture techniques for the inventory of bats. Journal of Mammalogy, 80(1):24-30. https://doi. org/10.2307/1383204

PARSONS, S., \& SZEWCZAK, J.M. (2009). Detecting, Recording, and Analyzing the Vocalizations of Bats. In: The ecological and behavioral methods for the study of bats. Ed.: The John Hopkins University Press, Baltimore, USA. p. 91-111.
PATTERSON, B.D., \& WEBALA, P.W. (2012). Keys to the Bats (Mammalia: Chiroptera) of East Africa. Fieldiana Life and Earth Sciences, 1-60. http://dx.doi.org/10.3158/21585520-12.6.1

RAINHO, A., AUGUSTO, A.M., \& PALMEIRIM, J.M. (2010). Influence of vegetation clutter on the capacity of ground foraging bats to capture prey. Journal of Applied Ecology, 47(4):850-858. https://doi.org/10.1111/j.13652664.2010.01820.x

RAUTENBACH, I.L., KEMP, A.C., \& SCHOLTZ, C.H. (1988). Fluctuations in availability of arthropods correlated with microchiropteran and avian predator activities. Koedoe. 31(1):77-90. https://doi.org/10.4102/koedoe.v31i1.486

RAZGOUR, O.N., KORINE, C., \& SALTZ, D. (2011). Does interspecific competition drive patterns of habitat use in desert bat communities? Oecologia, 167(2):493-502. https://doi.org/10.1007/s00442-011-1995-z

RUSSO, D., \& JONES, G. 2003. Use of foraging habitats by bats in a Mediterranean area determined by acoustic surveys: conservation implications. Ecography, 26(2):197-209. https://doi.org/10.1034/j.1600-0587.2003.03422.x

RYDELL, J., ENTWISTLE, A., \& RACEY, P.A. (1996). Timing of foraging flights of three species of bats in relation to insect activity and predation risk. Oikos, 76(2):243-252. https://doi.org/10.2307/3546196

SAMPAIO, E.M., KALKO, E.K.V., BERNARD, E., RODRIGUEZHERRERA, B., \& HANDLEY, C.O Jr. (2003). A biodiversity assessment of bats (Chiroptera) in a tropical lowland rainforest of Central Amazonia, including methodological and conservation considerations. Studies on Neotropical Fauna and Environmen, 38(1): 17-31. https://doi. org/10.1076/snfe.38.1.17.14035

SCHNITZLER, H.U., \& KALKO, E.K.V. (2001). Echolocation by insect-eating bats. BioScience, 51(7):557-569. https:// doi.org/10.1641/0006-3568(2001)051[0557:EBIEB]2.0. $\mathrm{CO} ; 2$

SIMMONS, J.A., FENTON, M.B., \& O'FARRELL, M.J. (1979). Echolocation and the pursuit of prey by bats. Science, 203(4375):16-21. https://doi.org/10.1126/ science. 758674

SIMMONS, N.B. (2005). Order Chiroptera. In: Mammal species of the world taxonomic and geographic reference. Ed.: The Johns Hopkins University Press, Baltimore, USA: p. 312-529.

STONE, E.L., JONES, G., \& HARRIS, S. (2012). Conserving energy at a cost to biodiversity? Impacts of LED lighting on bats. Global change Biology, 18(8):2458-2465. https://doi.org/10.1111/j.1365-2486.2012.02705.x

STUDIER, E.H., LYSENGEN, V.L., \& O' FARRELL, M.J. (1973). Biology of Myotis thysanodes and $M$. lucifugus (Chiroptera: Vespertilionidae)- II. Bioenergetics of pregnancy and lactation. Comp. Biocehm. Phys. A., 44(2):467-471. 
TAYLOR, R.J., \& O'NEILL, M.G. (1988). Summer activity patterns of insectivorous bats and their prey in Tasmania. Wildlife Research, 15(5):533-539. https://doi. org/10.1071/WR9880533

TAYLOR, P.J., GEISELMAN, C., KABOCHI, P., AGWANDA, B., \& TURNER, S. (2005). Intraspecific variation in the calls of some African bats (Order Chiroptera). Durban Museum Novitates, 30(1):24-37.

THIES, W., KALKO, E.K.V., \& SCHNITZLER, H.U. (1998). The roles of echolocation and olfaction in two Neotropical fruit-eating bats, Carollia perspicillata and C. castanea, feeding on Piper. Behavioral Ecology and Sociobiology, 42(6):397-409. https://doi.org/10.1007/s002650050454

THOMAS, D.W. (1988). The distribution of bats in different ages of Douglas-fir forests. The Journal of Wildlife Management, 52(4):619-628. https://doi. org/10.2307/3800920

TILMAN, D. (1999). Global environmental impacts of agricultural expansion: The need for sustainable and efficient practices. P. Natl. Acad. Sci. USA., 96(11):59956000. https://doi.org/10.1073/pnas.96.11.5995

TREITLER, J.T., HEIM, O., TSCHAPKA, M., \& JUNG, K. (2016). The effect of local land use and loss of forests on bats and nocturnal insects. Ecology and Evolution, 6(13):42894297. https://doi.org/10.1002/ece3.2160

TSCHARNTKE, T., KLEIN, A.M., KRUESS, A., STEFFANDEWENTER, I., \& THIES, C. (2005). Landscape perspectives on agricultural intensification and biodiversity-ecosystem service management. Ecology Letters, 8(8):857-874. https://doi.org/10.1111/j.1461-0248.2005.00782.x

VAN CAKENBERGHE, V., \& HAPPOLD, M. (2013). Pipistrellus rendalli Rendall's Pipistrelle. In: Mammals of Africa (Hedgehogs, Shrews and Bats). Ed.: Bloomsbury Publishing, London, United Kingdom, p. 645-647.

WALSH, A.L., \& HARRIS, S. (1996). Foraging habitat preferences of vespertilionid bats in Britain. Journal of Applied Ecology, 33(3):508-518. https://doi. org/10.2307/2404980

WEBALA, P.W., OGUGE, N.O., \& BEKELE, A. (2004). Bat species diversity and distribution in three vegetation communities of Meru National Park Kenya. African Journal of Ecology, 42(3):171-179. https://doi. org/10.1111/j.1365-2028.2004.00505.x
WEBALA, P.W., MURIUKI, G., LALA, F., \& BETT, A. (2006). The small mammal community of Mukogodo forest, Kenya. African Journal of Ecology, 44(3):363-370. https://doi. org/10.1111/j.1365-2028.2006.00634.x

WEBALA, P.W., CARUGA,T.I. L., CANOVA, L., \& FASOLA, M. (2009). Bat assemblages from Eastern Lake Turkana, Kenya. Ecologe, 64: 85-91.

WEBALA, P.W., CRAIG, M.D., LAW, B.S., ARMSTRONG, K.N., WAYNE, A.F., \& BRADLEY, J.S. (2011). Bat habitat use in logged jarrah eucalypt forests of south-western Australia. Journal of Applied Ecology, 48(2):398-406. https://doi. org/10.1111/j.1365-2664.2010.01934.x

WEBALA, P.W., MUSILA. S., \& MAKAU, R. (2014). Roost occupancy, roost site selection and diet of strawcoloured fruit bats (Pteropodidae: Eidolon helvum) in western Kenya: the need for continued public education. Acta chiropterologica, 16(1):85-94. https://doi. org/10.3161/150811014X683291

WECHULI, D.B., WEBALA, P.W., PATTERSON, B.D., \& OCHIENG, R.S. (2016). Bat species diversity and distribution in a disturbed regime at the Lake Bogoria National Reserve, Kenya. African Journal Ecology, 55(4):465-476. https:// doi.org/10.1111/aje.12376

WICKRAMASINGHE, L.P., HARRIS, S., JONES, G., \& VAUGHAN, N. (2003). Bat activity and species richness on organic and conventional farms: impact of agricultural intensification. Journal of Applied Ecology, 40(6):984-993. https://doi. org/10.1111/j.1365-2664.2003.00856.x

WILLIAMS-GUILLÉN, K., OLIMPI, E., MAAS, B., TAYLOR, P.J., \& ARLETTAZ, R. (2016). Bats in the Anthropogenic Matrix: Challenges and Opportunities for the Conservation of Chiroptera and Their Ecosystem Services in Agricultural Landscapes. In: Bats in the anthropocene: conservation of bats in a changing world. Eds. Springer International AG, New York. p. 151-185.

Yalden, D.W., \& Happold, M. (2013). Otomops martiensseni Large-eared Giant Mastiff Bat. In: Mammals of Africa (Hedgehogs, Shrews and Bats). Ed.: Bloomsbury Publishing, London, United Kingdom, p. 480-482. 